\title{
Preliminary Economic Feasibility Study of Ferromanganese Nodule Mining by Mechanical Lifting and Small-Scale Collectors
}

\author{
Sup Hong ${ }^{1}$, Hyung-Woo Kim ${ }^{1}$, Tae-Kyung Yeu ${ }^{1}$, Rei Arai ${ }^{2}$ and Tetsuo Yamazaki ${ }^{2, *(D)}$ \\ 1 Korea Research Institute of Ships and Ocean Engineering, Daejeon 34103, Korea; suphong@kriso.re.kr (S.H.); \\ hyungwoo4601@kriso.re.kr (H.-W.K.); yeutk@kriso.re.kr (T.-K.Y.) \\ 2 Graduate School of Engineering, Osaka Prefecture University, Sakai 599-8531, Japan; \\ arai@marine.osakafu-u.ac.jp \\ * Correspondence: yamazaki@marine.osakafu-u.ac.jp; Tel.: +81-72-254-8523
}

Citation: Hong, S.; Kim, H.-W.; Yeu,

T.-K.; Arai, R.; Yamazaki, T.

Preliminary Economic Feasibility

Study of Ferromanganese Nodule

Mining by Mechanical Lifting and

Small-Scale Collectors. Minerals 2021,

11, 1389. https://doi.org/10.3390/

$\min 11121389$

Academic Editor: Luis E. Lara

Received: 16 October 2021

Accepted: 2 December 2021

Published: 8 December 2021

Publisher's Note: MDPI stays neutral with regard to jurisdictional claims in published maps and institutional affiliations.

Copyright: (c) 2021 by the authors. Licensee MDPI, Basel, Switzerland. This article is an open access article distributed under the terms and conditions of the Creative Commons Attribution (CC BY) license (https:// creativecommons.org/licenses/by/ $4.0 /)$.

\begin{abstract}
Ferromanganese nodules have been recognized as a potential future metal source for over 50 years. Many research and development efforts have been conducted by many organizations. Most of the efforts have been concentrated into the mining technologies especially for hydraulic lifting through riser pipes with bulk-scale nodule collector. However, no commercial mining venture exists. Uncertainty in the economy of nodule mining is considered to be the reason for this. In order to improve the economy, a mining subsystem based on mechanical lifting and small-scale collectors is proposed and the preliminary economic feasibility is examined in this study. The benefit was at a favorable level compared with that using hydraulic lifting with bulk-scale collector. From the viewpoint of environmental impact assessment, environmental considerations of deep-sea sediment plume are explained.
\end{abstract}

Keywords: Clarion-Clipperton fracture zone; deep-sea mining; ferromanganese nodule; mechanical lifting; hydraulic lifting; synthetic rope; net bag; economic analysis

\section{Introduction}

\subsection{Geophysical and Technological Approches}

Many scientific, technical, and economic publications are available on ferromanganese nodules (FNs) because FNs have been considered to be the primary commercial mining target in deep-sea mineral resources for the past more than 50 years [1,2]. Geological distribution features were studied by many scientists [3-7]. On the basis of this information, the first mining target areas were in the Clarion-Clipperton fracture zone (CCZ) in the Northeast Pacific. The international consortium authorized their sites in US domestic law [8], and Pioneer Investors were assigned to be contractors with the International Seabed Authority (ISA) [9] in CCZ. The first stage of research and development (R\&D) activities for FN mining was conducted by the international consortium in the 1960s and 1970s [10-12]. Though some of the consortium's technological results were reported [13-18], most important data and results remain secret, especially for metallurgical processing and pilot-scale mining experiments.

The second stage of R\&D was followed by several national projects [19-24]. Many publications are available from the national projects and other studies regarding seafloor FN miner design [25-29], the hydraulic lifting characteristics of FNs in a pipeline [30-34], and the hydrodynamics of riser pipes [35-38].

Most mining subsystems considered in these R\&D efforts [10-38] were hydraulic lifting through riser pipes and bulk-scale collector. Only two exceptions were partially considered, shuttle miners [19] and bucket elevator [24], and a totally different one was small-scale collectors with flexible risers $[29,39]$. The shuttle miner system examined by 
French researchers was a feasibility study for a mining subsystem utilizing autonomous underwater vehicles (AUVs) [19]. The shuttle would descend down to the seafloor, gather FNs into the shuttle body, and autonomously return back to sea surface. However, hydraulic lifting through riser pipes and bulk-scale collector was selected as the mining subsystem [19]. The pipe bucket elevator studied by India was a lifting method [24], but the mining subsystem was changed to small-scale collectors with flexible risers [29,39]. Both shuttle miner and bucket elevator were considered inappropriate for bulk-scale FN production.

The continuous line bucket (CLB) system is an effective approach for small-scale mining, requiring a lower investment cost [40]. This concept utilizes a wireline with many buckets that is circulated from surface ship to seafloor. Buckets were designed to dip up FNs as they are towed across the seafloor. CLB was also considered to not be effective for bulk-scale FN production.

In 2008, at Chennai, India, ISA conducted a workshop to evaluate the technical and economic possibility of FN mining. The specifications of mining $5000 \mathrm{t} /$ day (1.5 Mt/year) in wet conditions, the transportation and metallurgical processing subsystems, and capital and operation expenditures (CAPEX and OPEX) of FN mining were discussed in the workshop. About 50 specialists in FN mining technologies, metallurgical processing, the economy, and international law of the sea attended. Mining and metallurgical processing methods and cost analysis models for FNs were first presented. Then, three working groups related to mining technology, metallurgical processing, and the economic model were created, and they reviewed published R\&D results and models. At the end of the workshop, CAPEX, OPEX, and methods for mining, transportation, metallurgical processing, and model selection in the working groups were reported. Four mining methods with different collectors and risers, and one processing method with hydrometallurgy were included in the report. The four mining methods involved using (a) a passive collector, (b) a tracked collector, (c) a Chinese collector with steel riser pipes, and (d) small tracked Indian collectors with flexible risers. The draft summary of the workshop was open to the public in 2008 [41] and the proceedings, including the presentation papers and the economic evaluation results applying all workshop results, were opened in 2012 [42]. Because the workshop was the last to gather many experts of different specialties related to FN mining, workshop results and the report [42] still have high-level value as reference for economic feasibility studies. One disadvantage of the economic evaluation results in the report [42] is that only hydrometallurgy was selected as the processing subsystem.

\subsection{Environmental Approaches}

Owing to growing concern for the environmental impacts of deep-sea mining to the seafloor and water column ecosystems, multidisciplinary environmental studies were conducted in different parts of the global oceans. Initial environmental impact studies of deep-sea mining were conducted prior to and during the pilot-scale mining tests for FNs in the 1970s [43-45]. They were followed by several small-scale experiments on the seafloors in the 1980s, creating benthic disturbances in the Pacific and Indian Oceans [46-54]. These studies included collections of baseline environmental data in the proposed FN mining areas, and the creation of experimentally disturbed areas that were comparable to expected mining and whose effects were monitored over a certain period of time. They aimed to project the intensity of mining impacts on different environmental parameters as well as to evaluate the processes of restoration and recolonization of the deep-sea ecosystems. However, all the durations and the scales of experiments were quite short and small compared with commercial-scale FN mining.

The Deep Ocean Mining Environment Study (DOMES; 1972-1981) [43] conducted by the National Oceanic and Atmospheric Administration (NOAA) of the USA monitored environmental impacts during two of the pilot-scale mining tests conducted by the international consortium in the CCZ of the Northeast Pacific [44,45]. The studies were important because the concentrations of particulates in the surface discharge created by lift water were measured. The disturbance and recolonization (DISCOL) experiment was conducted 
by the scientists of Hamburg University, Germany in the Southeast Pacific's Peru Basin in 1988-1998 [46]. Because the long term recovery process of the seafloor ecosystem was monitored, this was a milestone experiment. The results showed that, over a period of time, although certain groups of benthic organisms might show quantitative recovery, the faunal composition was not the same as the undisturbed [47]. This implied that complete recolonization was a slow process and some benthic organisms might need more time to re-establish themselves in the disturbed area in terms of density and diversity.

Four small-scale benthic impact experiments were conducted by NOAA [48], the Metal Mining Agency of Japan (MMAJ) [49], the InterOceanMetal (IOM) Joint Organization [50], and the National Institute of Oceanography, India [51] by using the Deep-Sea Sediment Resuspension System (DSSRS) [52] in the Northeast Pacific and the Indian Oceans (1991-1997). Some important results were observed from baseline studies and postdisturbance monitoring $[53,54]$.

\section{Economic Feasibility Analyses of Ferromanganese Nodule Mining}

\subsection{Previous Research}

Three economic feasibility studies on FN mining were conducted on the basis of earlier R\&D efforts, assuming basic geological and geophysical factors [55-57]. An economic feasibility study on cobalt-rich FNs inside the Cook Islands' EEZ [58] was unique because a smaller production scale and mechanical lift were assumed in the mining model. The results of these four feasibility studies are summarized and compared in Table 1. Because the market demand for manganese in the 1980s and 1990s was only 40\% of that in 2019 [59], manganese recovery from FN mining was not considered in some economic analyses [56,58]. Price reduction in the market due to the large amount of manganese supplied by multiple FN mining projects was thought to not be able to recover the additional metallurgical processing cost for manganese.

\subsection{Distribution Model of Ferromanganese Nodules}

Because the FN population and metal contents are very high in $\mathrm{CCZ}$, the international consortium inspected the FN distribution and authorized their sites under US domestic law [8]; Pioneer Investors presented their survey data to ISA and were awarded their sites as contractors [9]. An FN population of $10 \mathrm{~kg} / \mathrm{m}^{2}$ in wet conditions, as shown in Figure 1 $\left(7.2 \mathrm{~kg} / \mathrm{m}^{2}\right.$ in dry conditions), is the first target sites for FN mining in CCZ. The same value was selected as the FN population in the distribution model as in the previous study by the authors [48]. Though the water depth of CCZ is $4000-5500 \mathrm{~m}$, it was assumed to be $5000 \mathrm{~m}$ in the model. Depending on site locations, metal contents in FN are different, but the exemplary values of $1.12 \%$ of copper, $1.44 \%$ of nickel, and $0.2 \%$ of cobalt applied in a previous study by the authors [60] were selected as the metal contents of the distribution model. Because market demand for manganese in 2019 is about 2.5 times that of the 1980s and 1990s [59], manganese recovery from multiple FN mining projects was selected as the basis of an ISA's economic impact study for on-land mining [61]. A general value of $20 \%$ manganese content was selected in the distribution model. The metal contents of FNs used in this model are summarized in Table 2. A solid density of $3.25 \mathrm{~g} / \mathrm{cm}^{3}$ and porosity of $55 \%$ reported for FNs [62] were selected as the physical properties. 
Table 1. Summary and comparison of earlier economic feasibility studies for ferromanganese nodule mining.

\begin{tabular}{|c|c|c|c|c|c|c|c|c|c|c|c|c|}
\hline \multirow{2}{*}{$\begin{array}{c}\begin{array}{c}\text { Authors } \\
\text { Processing } \\
\text { Method }\end{array} \\
\text { Subsystem } \\
\end{array}$} & \multicolumn{3}{|c|}{$\begin{array}{c}\text { Andrews et al. [55] } \\
\text { Reduction and Hydrochloric Acid Leach Process }\end{array}$} & \multicolumn{3}{|c|}{$\begin{array}{l}\text { Hillman and Gosling [56] } \\
\text { Cuprion Ammoniacal Leach Process }\end{array}$} & \multicolumn{3}{|c|}{$\begin{array}{l}\text { Charles et al. [57] } \\
\text { Reduction and Hydrochloric Acid Leach Process }\end{array}$} & \multicolumn{3}{|c|}{$\begin{array}{c}\text { Søreide et al. [58] } \\
\text { High-Temperature and High-Pressure Sulfuric Acic } \\
\text { Leach Process }\end{array}$} \\
\hline & $\begin{array}{c}\text { Mining } \\
\text { (Wet) }\end{array}$ & $\begin{array}{l}\text { Trans. } \\
\text { (Dry) }\end{array}$ & $\begin{array}{l}\text { Process. } \\
\text { (Dry) }\end{array}$ & $\begin{array}{c}\text { Mining } \\
\text { (Wet) }\end{array}$ & $\begin{array}{l}\text { Trans. } \\
\text { (Dry) }\end{array}$ & $\begin{array}{c}\text { Process. } \\
\text { (Dry) }\end{array}$ & $\begin{array}{c}\text { Mining } \\
\text { (Wet) }\end{array}$ & $\begin{array}{l}\text { Trans. } \\
\text { (Dry) }\end{array}$ & $\begin{array}{c}\text { Process. } \\
\text { (Dry) }\end{array}$ & $\begin{array}{c}\text { Mining } \\
\text { (Wet) }\end{array}$ & $\begin{array}{l}\text { Trans. } \\
\text { (Dry) }\end{array}$ & $\begin{array}{c}\text { Process. } \\
\text { (Dry) }\end{array}$ \\
\hline $\begin{array}{l}\text { Production } \\
(t / y) \\
\text { Operation } \\
\text { days }\end{array}$ & $\begin{array}{c}2.3 \mathrm{M} \\
300 \text { days/year }\end{array}$ & $\begin{array}{c}1.5 \mathrm{M} \\
300 \text { days/year }\end{array}$ & $\begin{array}{c}1.5 \mathrm{M} \\
330 \text { days/year }\end{array}$ & $\begin{array}{c}4.2 \mathrm{M} \\
300 \text { days/year }\end{array}$ & $\begin{array}{c}3.0 \mathrm{M} \\
300 \text { days/year }\end{array}$ & $\begin{array}{c}3.0 \mathrm{M} \\
330 \text { days/year }\end{array}$ & $\begin{array}{c}2.3 \mathrm{M} \\
250 \text { days/year }\end{array}$ & $1.5 \mathrm{M}$ & $1.5 \mathrm{M}$ & $1.1 \mathrm{M}$ & $0.7 \mathrm{M}$ & $0.7 \mathrm{M}$ \\
\hline $\begin{array}{l}\text { Capital } \\
\text { expenditure } \\
\text { (CAPEX) }\end{array}$ & USD $180 \mathrm{mil}$ & USD $176 \mathrm{mil}$ & USD 513 mil & USD 590 mil & USD 310 mil & USD 727 mil & USD $282 \mathrm{mil}$ & USD $188 \mathrm{mil}$ & USD $470 \mathrm{mil}$ & USD $127 \mathrm{mil}$ & USD 93 mil & USD $271 \mathrm{mil}$ \\
\hline CAPEX ratio & $21 \%$ & $20 \%$ & $59 \%$ & $36 \%$ & $19 \%$ & $45 \%$ & $30 \%$ & $20 \%$ & $50 \%$ & $26 \%$ & $19 \%$ & $55 \%$ \\
\hline Equity/Loan & $100 / 0$ & & & $100 / 0$ & & & $50 / 50$ & & & $30 / 70$ & & \\
\hline $\begin{array}{c}\text { Operating } \\
\text { expenditure } \\
\text { (OPEX) } \\
\text { Loan interest } \\
\text { Survey cost }\end{array}$ & $\begin{array}{l}\text { USD } 45 \text { mil } \\
0 \% \\
\text { USD } 6 \text { mil }\end{array}$ & USD 25 mil & USD 165 mil & $\begin{array}{l}\text { USD } 77 \text { mil } \\
0 \% \\
\text { USD } 3 \text { mil }\end{array}$ & USD 37 mil & USD 111 mil & USD $48 \mathrm{mil}$ & USD 36 mil & USD 156 mil & $\begin{array}{l}\text { USD } 21.8 \mathrm{mil} \\
8 \% \\
\text { USD } 1.9 \mathrm{mil}\end{array}$ & USD $13.5 \mathrm{mil}$ & USD $22.9 \mathrm{mil}$ \\
\hline OPEX ratio & $19 \%$ & $11 \%$ & $70 \%$ & $34 \%$ & $16 \%$ & $50 \%$ & $20 \%$ & $15 \%$ & $65 \%$ & $38 \%$ & $23 \%$ & $39 \%$ \\
\hline Metal & Price & Recovery & Product & Price & Recovery & Product & Price & Recovery & Product & Price & Recovery & Product \\
\hline $\mathrm{Cu}$ & USD $1.25 / \mathrm{lb}$ & $95 \%$ & $15,675 \mathrm{t} /$ year & USD $1.17 / \mathrm{lb}$ & $92 \%$ & $28,704 \mathrm{t} /$ year & USD $0.95 / \mathrm{lb}$ & $95 \%$ & $17,810 \mathrm{t} /$ year & USD $1 / \mathrm{lb}$ & $97 \%$ & $1890 \mathrm{t} /$ year \\
\hline $\mathrm{Mn}$ & USD $0.4 / \mathrm{lb}$ & $93 \%$ & $404,550 \mathrm{t} /$ year & & & & USD $0.3 / \mathrm{lb}$ & $93 \%$ & $382,500 \mathrm{t} /$ year & & & \\
\hline $\begin{array}{l}\text { Taxes } \\
\text { NPV } \\
\text { IRR }\end{array}$ & $\begin{array}{l}46 \% \\
6.4 \%\end{array}$ & & & $\begin{array}{l}\text { Total } 29 \% \\
\quad 7.4 \%\end{array}$ & & & $12 \%$ & & & $\begin{array}{l}10 \% \\
\text { USD- } 81 \text { mil } \\
9.6 \%\end{array}$ & & \\
\hline
\end{tabular}




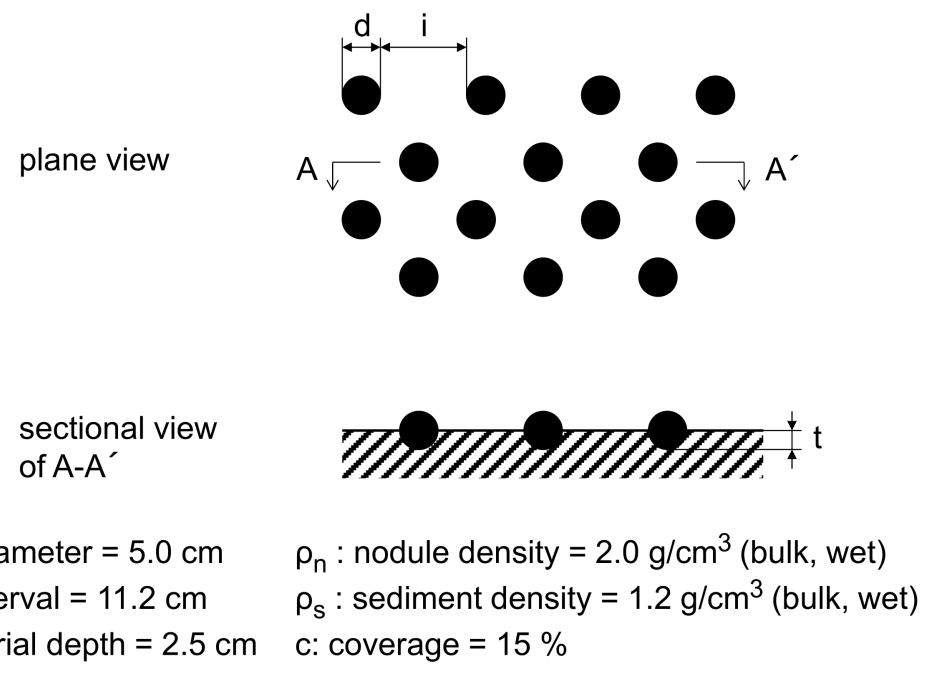

Figure 1. Ferromanganese nodule distribution model of $10 \mathrm{~kg} / \mathrm{m}^{2}$ (in wet conditions).

Table 2. Metal contents of ferromanganese nodules assumed in distribution model.

\begin{tabular}{cc}
\hline Metal & Content \\
\hline Copper & $1.12 \%$ \\
\hline Nickel & $1.44 \%$ \\
\hline Cobalt & $0.2 \%$ \\
\hline Manganese & $20 \%$ \\
\hline
\end{tabular}

FN population of $10 \mathrm{~kg} / \mathrm{m}^{2}$ (wet conditions) and $7.2 \mathrm{~kg} / \mathrm{m}^{2}$ (dry conditions) was the same as that in a previous study [60]. Other parameters introduced from a previous study [62].

\subsection{Production Model}

Obtained from the ISA workshop in 2008 [42], a specification of mining $5000 \mathrm{t} /$ day (1.5 Mt/year) in wet conditions by a tracked collector with a steel riser pipeline, and a transportation subsystem for $6000 \mathrm{~nm}$ was assumed as the basic FN production model. CAPEX and OPEX of the mining and the transportation subsystems calculated in the workshop were directly applied in this study.

As the metallurgical processing subsystem, the smelting and chlorine leaching method (SCL) was selected in this study. Most of proposed processing methods were examined in a Japanese metallurgical processing program [63], and SCL was concluded to have waste-free characteristics, though its cost was relatively higher than that of some hydrometallurgical methods. SCL was the best choice as a sustainable production model in this study. Obtained slag after the smelting was used as aggregates for constructions and the sulfur liquid after leaching is refreshed and reused for leaching. Recovery ratios of $80 \%$ for manganese and $94 \%$ for the three other metals in FNs with SCL [63] were assumed. CAPEX and OPEX of the SCL subsystem were calculated on the basis of the ones estimated for a pilot scale in the program [63], applying Equation (1):

$$
C_{\mathrm{A}}=C_{\mathrm{B}}\left(\frac{\mathrm{a}_{\mathrm{A}}}{\mathrm{a}_{\mathrm{B}}}\right)^{n}
$$

where $C_{\mathrm{A}}=$ value in this study; $C_{\mathrm{B}}=$ value in the reference study; $\mathrm{a}_{\mathrm{A}}=$ mass in this study; $\mathrm{a}_{\mathrm{B}}=$ mass in the reference study; $n=0.6$ scale factor [64].

In the mining model of FNs in this study, the following assumptions were basic conditions from FN mining technologies, feasibility studies, metallurgy, and other factors: 
- Hydraulic FN pick-up and mesh screening for sediments;

- Water depth of $5000 \mathrm{~m}$;

- Separation of lifted FNs and sediments;

- Drying FNs then transferring them to carrier vessels;

- Transportation distance of $6000 \mathrm{~nm}$ from CCZ to the processing location in Japan's mainland;

- Processed slag sales as concrete aggregate in $100 \mathrm{USD} / \mathrm{t}$;

- Calculating CAPEX and OPEX of processing using Equation (1) on the basis of Kojima [63] and Park et al. [65].

The important operation conditions in the production model are summarized in Table 3. Although 300 operational days per year in CCZ are too many in the case of open ocean areas, in ISA's economic evaluation, this condition was selected. Therefore, the same was assumed in this production model.

Table 3. Assumed important operation conditions in ferromanganese nodule production model.

\begin{tabular}{|c|c|}
\hline Condition & Concrete Figure \\
\hline Production per day & $5000 \mathrm{t}$ in wet \\
\hline Operation days & 300 days/year \\
\hline Water depth & $5000 \mathrm{~m}$ \\
\hline Transportation & 11,100 km (6000 nm) \\
\hline Duration of mining & $\begin{array}{l}25 \text { years ( } 4 \text { years for construction; } 1 \text { year for } \\
\text { test mining }{ }^{1} ; 20 \text { years for full operation) }\end{array}$ \\
\hline
\end{tabular}

\subsection{Hydraulic Lifting with Bulk-Scale Collector}

A hydraulic dredge utilizing a towed or tracked collector was the primary subsystem concept selected as the R\&D targets for bulk-scale FN production because of better reliability and greater production rate. The general concept of the hydraulic dredge with a tracked collector is shown in Figure 2. The three major components of the mining system are a bulk-scale seafloor collector, a lift riser, and in some cases with a buffer, a mining vessel on the sea surface. The collector was designed to pick up FNs (half-buried in seafloor sediments as shown in Figure 1) and send them via the lift riser through the feed regulating buffer to the surface. The pick-up mechanism uses water flow generated by a jet nozzle or water suction created by a pump. Water flow generated by submersible pumps or air injection (air lift) sends FNs up to the mining vessel through the riser. The production rate of commercial FN mining was assumed to be $5000 \mathrm{t}$ /day from 1980s because of the progress of dynamic structural analysis of the riser.

In this study, hydraulic lifting by a riser and submersible pumps with a bulk-scale tracked collector was assumed to be the reference concept of the production model.

\subsection{Mechanical Lifting by Synthetic Ropes with Small-Scale Collectors}

In this study, mechanical lifting by synthetic ropes with small-scale collectors is proposed to be the target concept of the production model. Two of the authors first proposed a concept of multiple collectors with mechanical rope lift and current-driven transportation system in 2009 [66]. It was a conceptual image of energy consumption minimized for FN mining and transportation system. An updated image of the mining subsystem assumed in this study is shown in Figure 3. Components were remotely operated small-scale collectors, surface vessel and platform, ROV, cables, lift ropes and their winches, and net bags filled with FNs. 


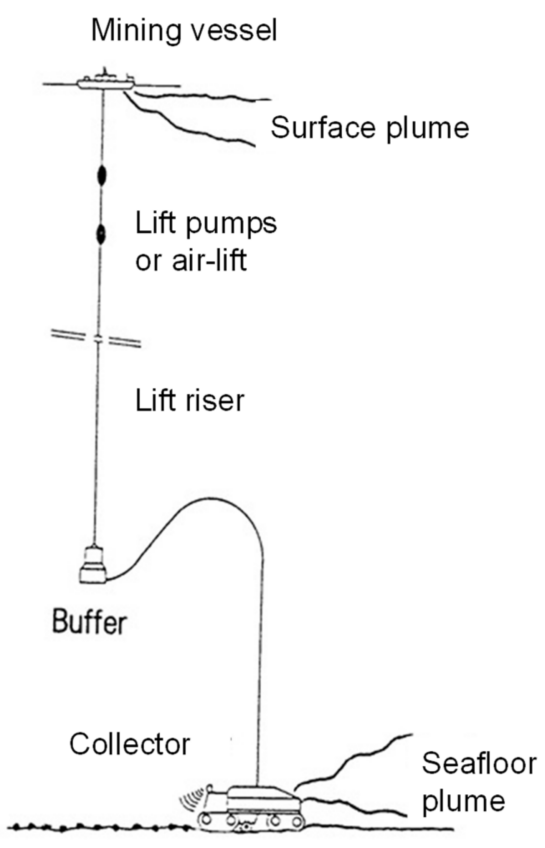

Figure 2. General concept of hydraulic lifting with bulk-scale collector.

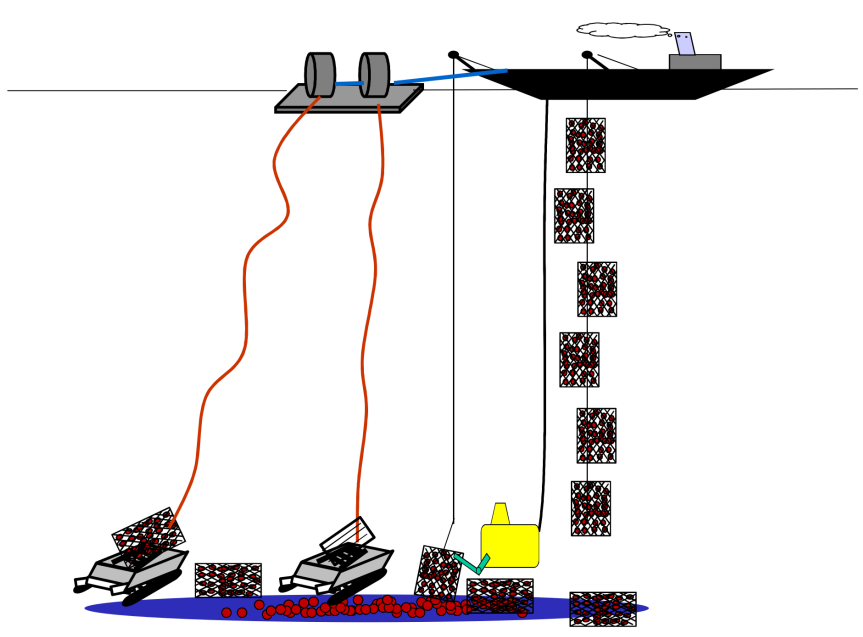

Figure 3. Concept of mechanical lifting with small-scale collectors.

An original small-scale collector, MineRo-II, was designed and built in 2012 as a component of Korean bulk-scale tracked collector [67]. With four hydraulic pick-up devices for FNs and four crawler tracks under $0.3 \mathrm{~m} / \mathrm{s}$ forward speed, FN collection ability was about $1000 \mathrm{t} /$ day, and four crushers and two discharge pumps to feed crushed FNs to lifting subsystem were installed on the body. Size ( $5 \mathrm{~m}$ (wide) with FN $4.5 \mathrm{~m}$ pick-up coverage, $6.5 \mathrm{~m}$ (long), $4 \mathrm{~m}$ (high)), the weight (28 ton (in air), 9 ton (in water)), and capability to operate at $5000 \mathrm{~m}$ water depth were the specifications of the collector. It was successfully tested in 2012 at $130 \mathrm{~m}$ water depth, and in 2013 at $1300 \mathrm{~m}$ water depth [68,69].

In this study, on the basis of the tested collector, a small-scale collector installed four crawler tracks, four hydraulic pick-up devices, two discharge pumps, a net bag bed, and a bag dumping mechanism with net bag mouth tie-up and release function were assumed as the basic components for a seafloor small-scale collector. Crushers and pumps installed on the tested collector were replaced by the net bag bed and the bag dumping mechanism. Power and weight are the same as the tested collector. The difference of the collector operation with the tested collector is FN flow and treatment in the collector. After hydraulic pick-up, FNs are induced and stored in a net bag placed on the bed by water stream created by discharge pumps. During this storing operation, sediments recovered 
with FNs are flashed out from the net bag by the water stream. The amount of sediments packed with nodules is very little. Then, the bag is released and dumped after every $10 \mathrm{t}(5 \mathrm{t}$ in water) FN accumulation in the bag. The bags lie on the seafloor and wait for recovery.

A unit mining system on the seafloor for $1250 \mathrm{t} /$ day was composed of two small-scale collectors, a synthetic rope with an end sinker weight, and an ROV. The two collectors collect FNs, move forward in parallel along planed paths, and place the net bags filled with FNs on the seafloor, as shown in Figure 4. One of the collectors moves 50-100 m ahead from the other. Following collector operation, the rope with the end sinker weight is deployed between the two paths. The ROV controls the drop point of the sinker weight and assists the rope deployment. Because of FN population, the width of FN pick-up, and the pick-up efficiency $(90 \%)$ by the collector, every $250 \mathrm{~m}$ is the distance between bags on the collector path. A layout image of the collector paths, the rope deployment, and the bags on the seafloor is shown in Figure 5. The bag installs a link rope and an end hook. Because the length of synthetic fiber Dyneema is limited to $130 \mathrm{~m}$, the unit length of the rope was $125 \mathrm{~m}$, and the units are connected by thimbles and shackles. The shackle point at every $125 \mathrm{~m}$ becomes the connection point of the hook of the bag. Thus, a connection point of the hook is there every $125 \mathrm{~m}$ in the lift rope as shown in Figure 5. The hook and shackle are connected by ROV as illustrated in Figure 6 . The synthetic fiber has the same tensile strength as that of steel wire and $0.97 \mathrm{~g} / \mathrm{cm}^{3}$ in specific gravity. The lift rope including thimbles and shackles thus has almost neutral weight in water. The net bag is composed of any kind of fiber, including natural.

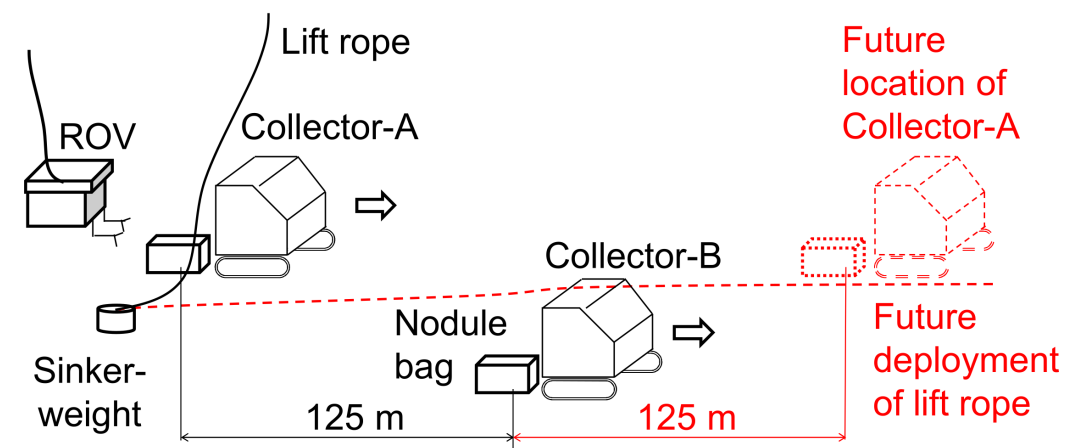

Figure 4. Image of collectors and ROV operations, and lift-rope deployment on the seafloor.

\section{Direction of system operation}

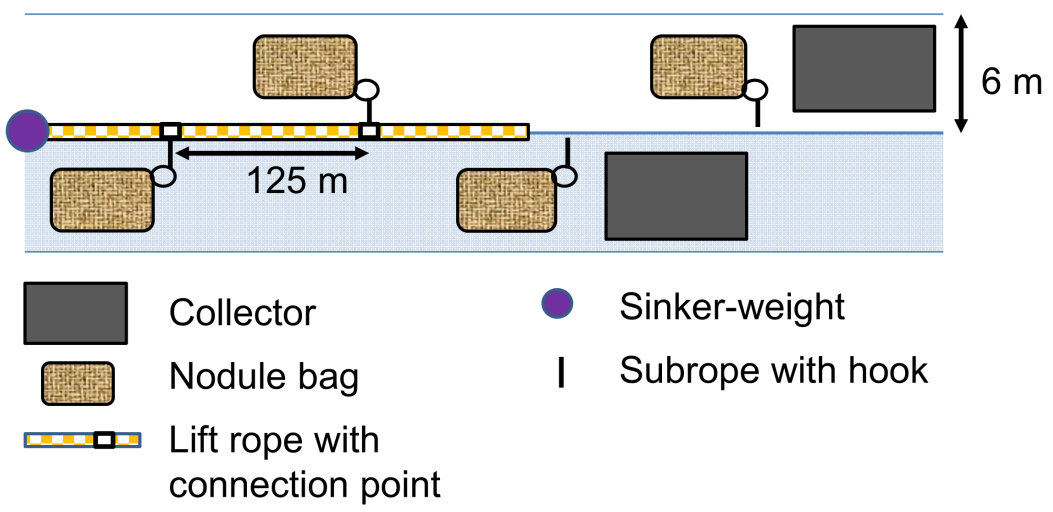

Figure 5. Layout image of collector paths, rope deployment, and bags on seafloor. 


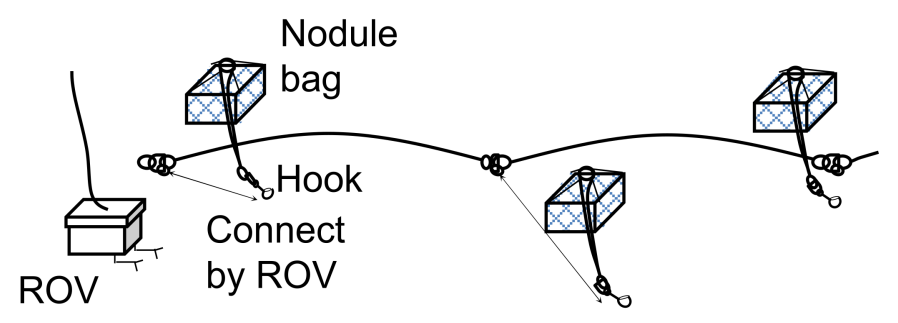

Figure 6. Image of bag and lift rope connection by ROV.

An extension of at least $8000 \mathrm{~m}$ of rope $(3000 \mathrm{~m}$ for bag connection and $5000 \mathrm{~m}$ for water depth) with 25 bags and recovery, takes about $4.5 \mathrm{~h}$ : $1.5 \mathrm{~h}$ for rope deployment, 1 $\mathrm{h}$ for rope and bag connection, and $2 \mathrm{~h}$ for lift-up. Five turns per day are necessary for the production of $1250 \mathrm{t}$ /day. Four mining systems are necessary for the production of $5000 \mathrm{t} /$ day. After storing FNs into a storage room on the platform, net bags are recovered for the next usage, and a bag package is prepared to descend to the seafloor with the sinker weight. At the seafloor, the bag package is delivered and fixed to the collectors by ROV.

\subsection{Economic Factors Applied in Analyses}

In this study, 10-year average prices of metals in 2008-2017 [59] are used. The prices of nickel, copper, cobalt, and manganese used for FN economic analyses are listed in Table 4. From the distribution and production models, and the metal prices in Table 4, the annual income by metal sales from the 6th to the 25th year was calculated to be about USD 938 mil.

Table 4. Metal prices used in economic analyses (average of 2008-2017) [59].

\begin{tabular}{cc}
\hline Metal & Price (USD/t) \\
\hline $\mathrm{Ni}$ & 16,121 \\
\hline $\mathrm{Cu}$ & 6678 \\
\hline $\mathrm{Co}$ & 34,698 \\
\hline $\mathrm{Mn}$ & 2463 \\
\hline
\end{tabular}

The CAPEX and OPEX of subsystems in the two FN production models in this study are listed in Table 5. Obtained results from the ISA workshop in 2008 [42] were directly used in this study showing specification of mining $5000 \mathrm{t} /$ day by hydraulic lifting with a tracked collector and a transportation subsystem for $6000 \mathrm{~nm}$. The values of mechanical lifting with small-scale collectors are also included in Table 5. The construction cost of MineRo-II is used as the base of calculation of the small-scale collector. On the basis of above-mentioned operational concept of the mechanical lifting by synthetic ropes with small-scale collectors, a basic design was conducted in 2015 by a ship design company. Some quotes were collected from ship building, rope manufacturing, and marine generator manufacturing companies in 2015, and CAPEX was calculated. OPEX was calculated on the basis of energy consumptions and estimated maintenance costs.

Table 5. CAPEX and OPEX of subsystems used in this study.

\begin{tabular}{|c|c|c|c|c|}
\hline Subsystem & \multicolumn{2}{|c|}{ CAPEX (USDM) } & \multicolumn{2}{|c|}{ OPEX (USDM) } \\
\hline \multirow{2}{*}{ Mining } & Hydraulic & Mechanical & Hydraulic & Mechanical \\
\hline & 563 & 795 & 96 & 144 \\
\hline Transportation & \multicolumn{2}{|c|}{495} & \multicolumn{2}{|c|}{93} \\
\hline Metallurgy & \multicolumn{2}{|c|}{1062} & \multicolumn{2}{|c|}{181} \\
\hline Total & 2120 & 2352 & 370 & 418 \\
\hline
\end{tabular}


CAPEX and OPEX of metallurgical processing by SCL of the production model were calculated on the basis of the ones estimated for the pilot-scale program [63] by applying Equation (1), as shown in Table 5.

\section{Results of Economic Analyses and Discussion}

The three economic measures of net present value (NPV) [70], the internal rate of return (IRR) [70], and the payback period (PP) [71] were calculated as shown in Table 6. NPV is a mathematical technique used to translate projected annual cash flow amounts into the present equivalent amounts using the discount factor. The discount factor determines the present value of future cash flows. Setting $N P V=0$, IRR is calculated by the following equation. Parameters used to determine NPV are as Equation (2):

$$
N P V=\sum_{t=1}^{n} \frac{B_{t}}{(1+i)^{t}}-\sum_{t=1}^{n} \frac{C_{t}}{(1+i)^{t}}
$$

where $B t=$ net cash inflow during the period $t ; C t=$ total initial investment costs (CAPEX); $i=$ internal rate of return (IRR); $t=$ number of time period (year); $n=$ duration of project (25 years). PP is simply calculated by Equation (3).

$$
\mathrm{PP}=\text { total initial investment costs }(\mathrm{CAPEX}) / \text { average annual profit of periods }
$$

Table 6. Results of economic analyses.

\begin{tabular}{cccccc}
\hline \multicolumn{3}{c}{ Hydraulic } & \multicolumn{3}{c}{ Mechanical } \\
\hline $\mathrm{NPV}^{1}$ (USD mil) & $\mathrm{IRR}^{2}(\%)$ & $\mathrm{PP}^{3}$ (Year) & NPV (USD) & IRR (\%) & PP (Year) \\
\hline 1777 & 13.2 & 8.3 & 892 & 9.7 & 9.1 \\
\hline${ }^{1}$ Net present value. ${ }^{2}$ Internal rate of return. ${ }^{3}$ Payback period.
\end{tabular}

Both results are economically very attractive, and hydraulic lifting is better. The OPEX of the mining subsystem in the case of hydraulic lifting is important. The lifetime of steel riser pipes of about $5000 \mathrm{~m}$ in open ocean area might be less than a couple of years, because the one measuring $1800 \mathrm{~m}$ in the inter-island sea area was estimated to last for 2-5 years [72]. In the OPEX of the hydraulic lifting model assumed in this study, the short lifetime was not considered because the original ISA model itself did not consider it [42]. In the CAPEX of the mining subsystem of hydraulic lifting, about $5 \%$ is used for steel riser pipes and about the same for submersible pumps, respectively. The lifetimes of riser pipes and submersible pumps for seafloor massive sulfides in the Okinawa Trough, $1700 \mathrm{~m}$ deep at open ocean area, were assumed to be 6 months and 1 year, respectively, in previous research [73]. About a 15\% increase in the OPEX of the mining subsystem was assumed in the economic evaluation study. The OPEX of the mining subsystem for hydraulic lifting might thus increase by $15 \%$ or more, depending on the lifetimes of the riser pipes and the submersible pumps. The return costs of lift water to a deeper water column was not included in the original ISA model [42]. Depending on the water depth necessary to return and discharge, the costs become higher. The lifetime of the synthetic rope might increase the OPEX of the mechanical lifting. Because no technical data are available, it is also necessary to collect them for improving economic analysis of mechanical lifting.

\section{Environmental Considerations}

\subsection{Estimations of Sediment Recovery and Re-Sedimentation Area}

The FN collector movement on the seafloor and the FN recovery mechanism cause large seafloor disturbances. Because of the half-buried distribution characteristics of FNs in the deep-sea sediment layer, large amounts of deep-sea sediments were recovered with FNs into the collector, and immediately separated and flushed out to the benthic water column. Impacts at the seafloor in the water column cannot be avoided, but they must be considered during the development of mining equipment and in designing the mining operations to 
minimize the effects. The maximal impact that needs to be estimated and reduced is the seafloor sediment plume. Depending on FN production rate and FN recovery mechanism, the amount of sediments recovered with FNs is different, but is several times more than the FN production was expected to be [74].

Seafloor photos taken by deep-sea camera systems after the deep-sea experiments are generally used for qualitative observations of the disturbed and re-sedimentation areas $[51,75,76]$, but quantitative usages are rare. In the postdisturbance monitoring of the MMAJ experiments, re-sedimentation was analyzed by a unique technique using the seafloor photos. The technique used color differences between PMs, black, and the sediments, light ocher, and the gradual changes in PM colors from black to light ocher caused by re-sedimentation [77]. The areal distribution of the re-sedimentation area was estimated to approximately be $3 \mathrm{~km}$ long and $2.5 \mathrm{~km}$ wide. The heavy re-sedimentation area, which was thicker than $0.26 \mathrm{~mm}$, was within $100 \mathrm{~m}$ from the towed tracks of DSSRS. The extent of the re-sedimentation area calculated from sediment trap data [78] and by a computer simulation program developed for dispersion analysis of resuspended sediments [79] agreed with the one from seafloor photo analysis. The maximal thickness of re-sedimentation was $2.6 \mathrm{~mm}$, about $13 \%$ of that expected in commercial mining [80].

\subsection{Large-Scale Deep-Sea Impact Experiments Scheduled and Simulation Studies}

The number of exploration contracts for FNs by ISA at 2021 is 19. Until 2010, exploration activities were predominantly undertaken by eight national agencies. Then, many private companies became involved and an FN mining industry was born. Some of them and the original agencies are planning to conduct pilot-scale collector tests in the FN distribution areas and the environmental monitoring under growing concern to minimize the impacts. There is a lot of information available from contractors, machinery companies, and institutions [81-84]. Pilot-scale collector tests are estimated to be large-scale.

The most in-depth information is related with prototype FN collector tests in German and Belgian contract areas in CCZ [82,84]. Some basic studies in and around the areas $[85,86]$, and numerical simulation studies of sediment plume $[87,88]$ were reported on the basis of some baseline cruises. The prototype collector test and large-scale impact experiment finished in 2021 [89].

Additional numerical simulation studies for sediment plume behavior in deep-sea water columns were reported [90,91]. The ground truth of the simulation results by the environmental monitoring of larger-scale deep-sea impact experiments is required for quantitative multidisciplinary impact and risk assessments of FN mining.

\subsection{Remaining Solution including Environmental Impact Assessment}

A very careful and detailed examination including environmental impact assessment must take place prior to start commercial-scale FN mining. The results of small-scale deep-sea environment impact experiments introduced in the previous sections showed that 10 years or more are necessary to recover to the baseline faunal composition of the seafloor ecosystem after the impact. The scheduled large-scale deep-sea impact experiments are good means to monitor environmental impacts and ecosystem recovery. The monitoring period of large-scale impact experiments should be 10 years or more to quantify ecosystem recovery. Commercial-scale FN mining is expected to be several times larger, and the duration would be 100+ times longer than that of the scheduled large-scale experiments. Ecosystem modelling of a recovery and simulation approach is expected for the environmental impact assessment.

\section{Advantage of Mechanical Lifting}

Hydraulic lifting through riser pipes for FN mining was proposed more than fifty years ago [92]. No other effective method could lift from $5000 \mathrm{~m}$ depth. Lifting up FNs from the seafloor to the sea surface was a probable solution, because offshore oil and gas exploration and production depth was shallower than $500 \mathrm{~m}$ [93]. However, a few offshore 
gas production projects were activated at $3000 \mathrm{~m}$ deep in 2020 [94]. Many remotely operated electric and mechanical facilities are used at the seafloor under long maintenance periods with reliable operations. Protecting marine ecosystems and maintaining biodiversity in the oceans are, however, essential requirements. Though many potential metal resources in the oceans, including FNs, are of interest to industries, minimizing impact to marine ecosystems and their diversity from mining activities is required. Therefore, a milder and gentler method, mechanical lifting, for FN mining is needed.

The two great advantages of mechanical lifting are no water discharge and less energy consumption than that of hydraulic lifting. In the case of hydraulic lifting, the volumetric transportation condition in riser pipes is $80-90 \%$ water and $10-20 \%$ ores [14-16,30-34]. After ore separation, the lifted water, which includes sediment particles and nodule powders, is discharged into the ocean water column and produces sediment plume [10-12,43-45,74]. Environmental impacts around the spot are expected due to the discharge, and the sediment plume then migrates and spreads in the water column [43-45]. In case of mechanical lifting, sediment particles and nodule powders are discharged into the water column from net bags during lifting. However, the discharge is not concentrated into a spot, and no sediment plume is created.

In case of mechanical lifting, lifting energy needs to overcome ore weight and fluid resistance for lift-up. Additionally, tracking energy to overcome fluid resistance against the rope and net bag line is necessary for FN collection operation. In the case of hydraulic lifting, lifting energy, including water stream creation in the riser pipes, and tracking energy, including heavy riser and pumps hanging from a surface platform, become larger than the ones of mechanical lifting.

\section{Concluding Remarks}

A new mining subsystem based on mechanical lifting and small-scale collectors was proposed, and its economic feasibility was examined and compared with hydraulic lifting and bulk-scale collector in this study. The economics calculated by both subsystems are interesting and favorable, though an expensive metallurgical processing method was selected in the production model. The most important point of this study was to introduce mechanical lifting and small-scale collectors as a possible mining subsystem for ferromanganese nodule mining. In the case of hydraulic lifting and bulk-scale collector, two major points must be clarified: the lifetime of riser pipes and lift water discharge. Without these clarifications, ferromanganese nodule mining by hydraulic lifting and bulk-scale collector cannot proceed to commercial venture stage. Some additional R\&D of mining technologies is necessary for both subsystems. In the case of mechanical lifting and small-scale collectors, the lifetime of synthetic rope is a target for clarification.

Very careful and detailed examination, including environmental impact assessment, must occur prior to commercial ventures for FN mining. Large-scale deep-sea impact experiments are good ways to monitor environmental impacts and ecosystem recovery. Many years are necessary to obtain enough information to conduct quantified environmental impact assessments.

Though much attention is focused on the development of ferromanganese nodules as future metal resources, further economic and environmental clarifications are required.

Author Contributions: Conceptualization, S.H. and T.Y.; methodology, H.-W.K. and T.-K.Y.; software, T.Y.; validation, S.H. and R.A.; investigation, H.-W.K., T.-K.Y., R.A. and T.Y.; resources, H.-W.K. and T.-K.Y.; data curation, T.Y.; writing-original draft preparation, T.Y.; writing-review and editing, S.H.; visualization, T.Y.; supervision, S.H.; project administration, S.H. All authors have read and agreed to the published version of the manuscript.

Funding: This research received no external funding.

Data Availability Statement: Restrictions apply to the availability of the data used. Data was obtained from KRISO and Osaka Prefecture University and are available from the coresponding author with the permission of both organizations. 
Acknowledgments: The authors deeply thank the three companies, Kansai Design Company, Ltd., Tokyo Seiko Rope MFG. Co., Ltd., Daihatsu Diesel MFG. Co., Ltd., for their individual partial contributions of basic designs and quotations of the mechanical lifting.

Conflicts of Interest: The authors declare no conflict of interest.

\section{References}

1. Mero, J.L. The Mineral Resources of the Sea; Oceanography Series, 1; Elsevier: Amsterdam, The Netherlands, $1965 ;$ p. 312.

2. Cronan, D.S. Underwater Minerals; Academic Press: London, UK, 1980; p. 362.

3. Craig, J.D.; Andrews, J.E. A Factor Analysis Study of Deep Sea Ferromanganese Deposits in the Equatorial North Pacific Ocean. Mar. Min. 1978, 1, 305-326.

4. Andrews, J.E.; Friedrich, G.H.W. Distribution Patterns of Manganese Nodule Deposits in the Northeast Equatorial Pacific. Mar. Min. 1979, 2, 1-43.

5. Friedrich, G.; Glasby, G.P.; Thijssen, T.; Plüger, W.L. Morphological and Geochemical Characteristics of Manganese Nodules Collected from Three Areas on an Equatorial Pacific Transect by RV Sonne. Mar. Min. 1983, 4, 167-253.

6. Von Stackelberg, U.; Beiersdorf, H. The Formation of Manganese Nodules between the Clarion Clipperton Fracture Zones Southeast of Hawaii. Mar. Geol. 1991, 98, 411-423. [CrossRef]

7. Morgan, C.L.; Nichols, J.A.; Selk, B.W.; Toth, J.R.; Wallin, C. Preliminary Analysis of Exploration Data from Pacific Deposits of Manganese Nodules. Mar. Georesour. Geotechnol. 1993, 11, 1-25. [CrossRef]

8. Padan, J.W. Commercial Recovery of Deep—Seabed Manganese Nodules: Twenty Years of Accomplishments. Mar. Min. 1990, 9, 87-103.

9. ISA. Plans of Work for Exploration of Government of India, IFREMER/AFERNOD, DORD, Yuzhmorgeologiya, COMRA, IOM, Republic of Korea; Report of the Secretary General No. ISBA/4/A/1/Rev.2; International Seabed Authority: Kingston, Jamaica, $1998 ;$ p. 47.

10. Welling, C.G. An advanced design deep sea mining system. In Proceedings of the 13th Offshore Technology Conference, Houston, TX, USA, 4-7 May 1981.

11. Kaufman, R.; Latimer, J.P.; Tolefson, D.C.; Senni, S. The design and operation of a Pacific Ocean deep ocean mining test ship: R/V Deepsea Miner II. In Proceedings of the 17th Offshore Technology Conference, Houston, TX, USA, 6-9 May 1985.

12. Bath, A.R. Deep sea mining technology: Recent developments and future projects. In Proceedings of the 21st Offshore Technology Conference, Houston, TX, USA, 1-4 May 1989.

13. Heine, O.R.; Suh, S.L. An Experimental Nodule Collection Vehicle Design and Testing. In Proceedings of the 10th Offshore Technology Conference, Houston, TX, USA, 8-11 May 1978.

14. Clauss, G. Hydraulic Lifting in Deep-Sea Mining. Mar. Min. 1978, 1, 189-208.

15. Burns, J.Q.; Suh, S.L. Design and Analysis of Hydraulic Lift Systems for Deep Ocean Mining. In Proceedings of the 11th Off-shore Technology Conference, Houston, TX, USA, 30 April 1979.

16. Grote, P.B.; Burns, J.Q. System Design Considerations in Deep Ocean Mining Lift System. Mar. Min. 1981, 2, $357-383$.

17. Chung, J.S.; Whitney, A.K.; Loden, W.A. Nonlinear Transient Motion of Deep Ocean Mining Pipe. J. Energy Resour. Technol. 1981, 103, 2-10. [CrossRef]

18. Kollwentz, W. Lessons Learned in the Development of Nodule Mining Technology. Mater. Soc. 1990, 14, $285-298$.

19. Herrouin, G.; Lenoble, J.; Charles, C.; Mauviel, F.; Bernard, J.; Taine, B. A manganese nodule industrial venture would be profitable-Summary of a 4-year study in France. In Proceedings of the 21st Annual Offshore Technology Conference, Houston, TX, USA, 1-4 May 1989.

20. Kotlinski, R. InterOceanMetal Joint Organization: Achievements and Challenges. In Proceedings of the 1st ISOPE Ocean Mining Symposium, Tsukuba, Japan, 21-22 November 1995; pp. 5-7.

21. Yang, N.; Wang, M. New Era for China Manganese Nodules Mining: Summary of Last Five Years' Research Activities and Prospective. In Proceedings of the 2nd ISOPE Ocean Mining Symposium, Seoul, Korea, 24-26 November 1997; pp. 8-11.

22. Yamada, H.; Yamazaki, T. Japan's Ocean Test of the Nodule Mining System. In Proceedings of the 8th International Offshore and Polar Engineering Conference, Montreal, QC, Canada, 24-29 May 1998; pp. 13-19.

23. Hong, S.; Kim, K.-H. Research and Development of Deep Seabed Mining Technologies for Polymetallic Nodules in Korea. In Proceedings of the Proposed Technologies for Deep Seabed Mining of Polymetallic Nodules, International Seabed Authority, Kingston, Jamaica, 3-6 August 1999; pp. 261-283.

24. Muthunayagam, A.E.; Das, S.K. Indian polymetallic nodule program. In Proceedings of the 3rd ISOPE Ocean Mining Sym-posium, Goa, India, 8-11 November 1999; pp. 1-5.

25. Li, L.; Zhang, J. The China's Manganese Nodules Miner. In Proceedings of the 2nd ISOPE Ocean Mining Symposium, Seoul, Korea, 24-26 November 1997; pp. 95-99.

26. Yasukawa, H.; Ikegami, K.; Minami, T. Motion Analysis of a Towed Collector for Manganese Nodule Mining in Ocean Test. In Proceedings of the 9th International Offshore and Polar Engineering Conference, Brest, France, 30 May-4 June 1999; pp. 100-107.

27. Hong, S.; Choi, J.-S.; Kim, J.-H.; Yang, C.-H. Experimental Study on Hydraulic Performance of Hybrid Pickup Device of Manganese Nodule Collector. In Proceedings of the 3rd ISOPE Ocean Mining Symposium, Goa, India, 8-11 November 1999; pp. 69-77. 
28. Yamazaki, T.; Kuboki, E.; Yoshida, H. Tracing Collector Passes and Preliminary Analysis of Collector Operation. In Proceedings of the 3rd ISOPE Ocean Mining Symposium, Goa, India, 8-11 November 1999; pp. 55-62.

29. Deepak, C.R.; Shajahan, M.A.; Atmanand, M.A.; Annamalai, K.; Jeyamani, R.; Ravindran, M.; Schulte, E.; Handschuh, R.; Panthel, J.; Grebe, H.; et al. Developmental Test on the Underwater Mining System Using Flexible Riser Concept. In Proceedings of the 4th ISOPE Ocean Mining Symposium, Szczecin, Poland, 23-27 September 2001; pp. 94-98.

30. Bernard, J.; Bath, A.R.; Greger, B. Analysis and comparison of nodule hydraulic transport systems. In Proceedings of the 9th Offshore Technology Conference, Houston, TX, USA, 27-30 April 1987; p. 5476.

31. Saito, T.; Usami, T.; Yamazaki, T.; Tomishima, Y.; Kiyono, F. Lifting Characteristics of Manganese Nodules by Air-Lift-Pump on 200m Vertical Test Plant. In Proceedings of the OCEANS'89, Seattle, WA, USA, 8-21 September 1989; pp. 48-53.

32. Xia, J.; Xia, L.; Zau, W.; Tang, D.; Huang, J.; Wang, S. Studies on Reasonable Hydraulic Lifting Parameters of Manganese Nodules. In Proceedings of the 2nd ISOPE Ocean Mining Symposium, Seoul, Korea, 24-26 November 1997; pp. 112-116.

33. Yoon, C.-H.; Kwon, K.-S.; Kwon, O.-K.; Kwon, S.-K.; Kim, I.-K.; Lee, D.-K.; Lee, H.-S. An Experimental Study on Lab Scale Air-Lift Pump Flowing Solid-Liquid-Air Three-Phase Mixture. In Proceedings of the 10th International Offshore and Polar Engineering Conference, Seattle, WA, USA, 27 May-2 June 2000; pp. 515-521.

34. Chung, J.S.; Lee, K.; Tischler, A.; Yarim, G. Effect of Particle Size and Concentration on Pressure Gradient in Two-Phase Ver-tically Upward Transport. In Proceedings of the 4th ISOPE Ocean Mining Symposium, Szczecin, Poland, 23-27 September 2001; pp. 132-138.

35. Aso, K.; Kan, K.; Doki, H.; Ohkoshi, T. The Effect of Vibration Absorbers on the Longitudinal Vibration of a Pipe String in the Deep Sea-Part 2: A Case of Mining Manganese Nodules. Int. J. Offshore Polar Eng. 1994, 4, 62-67.

36. Chung, J.S.; Cheng, B.-R.; Huttelmaier, H.P. Three-Dimensional Coupled Responses of a Vertical Deep-Ocean Pipe: Part II. Excitation at Pipe Top and External Torsion. Int. J. Offshore Polar Eng. 1994, 4, 321-339.

37. Cheng, B.-R.; Chung, J.S. Effects of Axial Dampers and Elastic Joints on 3-D Dynamic Responses of a Deep-Ocean Pipe with Torsional Coupling. Int. J. Offshore Polar Eng. 1997, 7, 36-43.

38. Ohta, T.; Morikawa, M. Bending Strength of Lifting Pipes Handling of Pipe Connection in Manganese Mining System. In Proceedings of the 2nd ISOPE Ocean Mining Symposium, Seoul, Korea, 24-26 November 1997; pp. 68-74.

39. Handschuh, R.; Grebe, H.; Panthel, J.; Schulte, E.; Wenzlawski, B.; Schwarz, W.; Atmanand, M.A.; Jeyamani, R.; Shajahan, M.; Deepak, R.; et al. Innovative Deep-Ocean Mining Concept Based on Flexible Riser and Self-propelled Mining Machine. In Proceedings of the 4th ISOPE Ocean Mining Symposium, Szczecin, Poland, 23-27 September 2001; pp. 99-107.

40. Masuda, Y.; Cruickshank, M.J. Study of the CLB Mining System for Nodule \& Crust Recovery. In Proceedings of the 1st ISOPE Ocean Mining Symposium, Tsukuba, Japan, 21-22 November 1995; pp. 91-97.

41. ISA. Report on the International Seabed Authority's Workshop on Polymetallic Nodule Mining Technology: Current Status and Challenges Ahead. Available online: https://www.isa.org.jm/files/documents/EN/14Sess/LTC/ISBA-14LTC-3.pdf (accessed on 26 October 2020).

42. ISA. Polymetallic Nodule Mining Technology: Current Status and Challenges Ahead. In Proceedings of the Workshop jointly organized by the International Seabed Authority and the Ministry of Earth Sciences, Government of India, National Institute of Ocean Technology, Chennai, India, 18-22 February 2008. Available online: https:/ /www.isa.org.jm/files/documents/EN/ Workshops /2008/Chennai/Chennai-FINAL.pdf (accessed on 21 May 2021).

43. DOMES. Summary of the Minutes of the DOMES Mining Industry Meeting; NOAA Pacific Marine Environmental Laboratory: Seattle, WS, USA, 1976; 12p.

44. Burns, R.E.; Erickson, B.H.; Lavelle, J.W.; Ozturgut, E. Observation and Measurements during the Monitoring of Deep Ocean Manganese Nodule Mining Tests in the North Pacific, March-May 1978, NOAA Technical Memorandum ERL MESA-47; US Department of Commerce, National Oceanic and Atmospheric Administration, Environmental Research Laboratories: Silver Spring, MD, USA, 1980.

45. Ozturgut, E.; Lavelle, J.W.; Steffin, O.; Swift, S.A. Environmental Investigation during Manganese Nodule Mining Tests in the North Equatorial Pacific, in November 1978, NOAA Technical Memorandum ERL MESA-48; Environmental Research Laboratories: Tuscon, AZ, USA, 1980.

46. Foell, E.J.; Thiel, H.; Schriever, G. DISCOL: A Longterm Largescale Disturbance-Recolonisation Experiment in the Abyssal Eastern Tropical Pacific Ocean. In Proceedings of the 24th Offshore Technology Conference, Houston, TX, USA, 7-10 May 1990. Paper No. 6328.

47. Schriever, G.; Ahnert, A.; Borowski, C.; Thiel, H. Results of the Large Scale Deep-Sea Impact Study DISCOL during Eight Years of Investigation. In Proceedings of the Seventh International Offshore and Polar Engineering Conference, Honolulu, HI, USA, 25-30 May 1997; pp. 438-444.

48. Trueblood, D.D. US Cruise Report for BIE-II Cruise, NOAA Technical Memo OCRS 4; National Oceanic and Atmospheric Administration, National Ocean Service: Silver Spring, MD, USA, 1993; 51p.

49. Fukushima, T. Overview "Japan Deep-sea Impact Experiment = JET". In Proceedings of the 1st ISOPE Ocean Mining Symposium, Tsukuba, Japan, 21-22 November 1995; pp. 47-53.

50. Tkatchenko, G.; Radziejewska, T.; Stoyanova, V.; Modlitba, I.; Parizek, A. Benthic Impact Experiment in the IOM Pioneer Area: Testing for Effects of Deep-sea Disturbance. In Proceedings of the International Seminar on Deep Sea-Bed Mining Technology, Beijing, China, 18-20 October 1996; pp. C55-C68. 
51. Sharma, R. Assessment of Impact on Seafloor Features in INDEX Area. Mar. Georesources Geotechnol. 2000, 18, 237-250. [CrossRef]

52. Brockett, T.; Richards, C.Z. Deepsea Mining Simulator for Environmental Impact Studies: "Benthic Disturber" Designed to Assist Multinational Team Assess Impact of Ocean Nodule Mining. Sea Technol. 1995, 35, 77-82.

53. Trueblood, D.D.; Ozturgut, E.; Pilipchuk, M.; Gloumov, I.F. The Ecological Impacts of the Joint U.S.-Russian Benthic Impact Experiment. In Proceedings of the 2nd ISOPE Ocean Mining Symposium, Seoul, Korea, 24-26 November 1997; pp. 139-145.

54. Shirayama, Y. Biological Results of the JET Project: An Overview. In Proceedings of the 3rd ISOPE Ocean Mining Symposium, Goa, India, 8-10 November 1999; pp. 185-190.55.

55. Andrews, B.V.; Flipse, J.E.; Brown, F.C. The Economic Viability of a Four-Metal Pioneer Deep Ocean Mining Venture; PB84-122563; US Department of Commerce: Washington, DC, USA, 1983; p. 201.

56. Hillman, C.T.; Gosling, B.B. Mining Deep Ocean Manganese Nodules: Description and Economic Analysis of a Potential Venture; IC 9015; US Bureau of Mines: Washington, DC, USA, 1985; p. 19.

57. Charles, C.; Herrouin, G.; Mauviel, F.; Bernard, J. Views on Future Nodule Technologies Based on IFREMER-GEMONOD Studies. Mater. Soc. 1990, 14, 299-326.

58. Søreide, F.; Lund, T.; Markussen, J.M. Deep Ocean Mining Reconsidered a Study of the Manganese Nodule Deposits in Cook Island. In Proceedings of the 4th ISOPE Ocean Mining Symposium, Szczecin, Poland, 23-27 September 2001; pp. 88-93.

59. Honkawa Data Tribune. Available online: https://honkawa2.sakura.ne.jp/5500.html (accessed on 26 December 2020). (In Japanese)

60. Yamazaki, T.; Park, S.-H.; Shimada, S. Development of Technical and Economical Examination Method for Cobalt-Rich Manganese Crusts. In Proceedings of the 12th International Offshore and Polar Engineering Conference, Kita-Kyushu, Japan, 26-31 May 2002; pp. 454-461.

61. ISA. Study of the Potential Impact of Polymetallic Nodules Production from the Area on the Economies of Developing Land-based Producers of Those Metals Which Are Likely to Be Most Seriously Affected. Available online: https://www.isa.org.jm/news/isareleases-study-potential-impact-mineral-production-international-seabed-area-economies (accessed on 26 December 2020).

62. Yamazaki, T.; Tomishima, Y.; Handa, K.; Saito, T. Studies on Characteristics of Friability of Manganese Nodules and on their Friability in the On-Board Facilities. Shigen; National Research Institute of Resources and Environment: Tsukuba, Japan, 1990; Volume 2, pp. 339-350. (In Japanese with English Abstract)

63. Kojima, K. Review of Studies on Manganese Nodules Processing. In Proceedings of the 2nd ISOPE Ocean Mining Symposium, Seoul, Korea, 24-26 November 1997; pp. 19-22.

64. Japan Coal Development Technology Cooperation Center. Mine Investment Analysis, Overseas Coal Development Technical Guide; Japan Coal Development Technology Cooperation Center: Tokyo, Japan, 1993; Volume 2, p. 55. (In Japanese)

65. Park, S.; Yamazaki, T.; Shimada, S.; Yamamoto, T. Development of Potential Examination Method for Cobalt-rich Manganese Crusts. J. Min. Mater. Process. Inst. Jpn. 2002, 118, 641-649. (In Japanese with English Abstract)

66. Yamada, A.; Yamazaki, T.; Arai, R.; Nakatani, N. Combined Analysis of Ecology and Economy of Manganese Nodule Mining. In Proceedings of the 8th ISOPE Ocean Mining Symposium, Chennai, India, 20-24 September 2009; pp. 73-79.

67. Lee, C.-H.; Kim, H.-W.; Hong, S. A Study on Dynamic Behaviors of Pilot Mining Robot according to Extremely Cohesive Soft Soil Properties. In Proceedings of the 10th Ocean Mining and Gas Hydrate Symposium, Szczecin, Poland, 22-26 September 2013; pp. 210-214.

68. Yeu, T.-K.; Yoon, S.-M.; Hong, S.; Kim, J.-H.; Kim, H.-W.; Choi, J.-S.; Min, C.-H. Operating System of KIOST Pilot Mining Robot in Inshore Test. In Proceedings of the 10th Ocean Mining and Gas Hydrate Symposium, Szczecin, Poland, 22-26 September 2013; pp. 265-268.

69. Hong, S.; Kim, H.-W.; Yeu, T.-K.; Choi, J.-S.; Yoon, S.-M.; Kim, J.-H.; Lee, C.-H.; Min, C.-H.; Lee, M.-U.; Sung, K.-Y.; et al. Pilot Mining Robot for Polymetallic Nodules and Pre-Pilot Mining Tests. In Proceedings of the 42nd Under Water Mining Institute, Rio de Janeiro, Brazil, 21-29 October 2013; pp. 1-6.

70. Investopedia. Internal Rate of Return (IRR). Available online: https://www.investopedia.com/terms/i/irr.asp (accessed on 9 November 2021).

71. Investopedia. Payback Period. Available online: https://www.investopedia.com/terms/p/paybackperiod.asp (accessed on 9 November 2021).

72. Stanton, P.; Yu, A. Interim Use of API Codes for the Design of Dynamic Riser Systems for the Deepsea Mining Industry. In Proceedings of the 29th International Conference on Ocean, Offshore and Arctic Engineering, Shanghai, China, 6-11 June 2010. OMAE2010-20189.

73. Okuhara, K.; Nakatani, N.; Arai, R.; Yamazaki, T. Technical and Economic Examinations of Mechanical Lift system for Seafloor Massive Sulfide Mining. In Proceedings of the 27th Ocean Engineering Symposium, Tokyo, Japan, 7-8 August 2018. OES27-037. (In Japanese with English Abstract)

74. Yamazaki, T.; Tsurusaki, K.; Handa, K. Discharge from Manganese Nodule Mining System. In Proceedings of the 1st International Offshore and Polar Engineering Conference, Edinburgh, UK, 11-16 August 1991; pp. 440-446.

75. Lavelle, J.W.; Ozturgut, E.; Swift, S.A.; Erickson, B.H. Dispersal and Resedimentation of the Benthic Plume from Deep-sea Mining Operations: A Model with Calibration. Mar. Min. 1981, 3, 59-93.

76. Spiess, F.N.; Hessler, R.; Wilson, G.; Weydert, M.; Rude, P. ECOH I Cruise Report; Scripps Institution of Oceanography: San Diego, CA, USA, 1984. [CrossRef] 
77. Yamazaki, T.; Kaijitani, Y.; Barnett, B.; Suzuki, T. Development of Image Analytical Technique for Resedimentation Induced by Nodule Mining. In Proceedings of the 2nd ISOPE Ocean Mining Symposium, Seoul, Korea, 24-26 November 1997; pp. 159-164.

78. Barnett, B.; Suzuki, T. The Use of Kringing to Estimate Resedimentation in the JET Experiment. In Proceedings of the International Symposium on Environmental Studies for Deep-Sea Mining, Tokyo, Japan, 20-21 November 1997; Metal Mining Agency of Japan: Tokyo, Japan, 1997; pp. 143-151.

79. Nakata, K.; Kubota, M.; Aoki, S.; Taguchi, K. Dispersion of Resuspended Sediments by Ocean Mining Activity-Modeling Study. In Proceedings of the International Symposium on Environmental Studies for Deep-sea Mining, Tokyo, Japan, 20-21 November 1997; Metal Mining Agency of Japan: Tokyo, Japan, 1997; pp. 169-186.

80. Yamazaki, T.; Kajitani, Y. Deep-sea Environment and Impact Experiment to It. In Proceedings of the 9th International Offshore and Polar Engineernig Conference, Brest, France, 30 May-4 June 1999; pp. 374-381.

81. Kang, Y.; Liu, S. The Development History and Latest Progress of Deep-Sea Polymetallic Nodule Mining Technology. Minerals 2021, 11, 1132. [CrossRef]

82. Global Sea Mineral Resources (GSR). Deep Seabed Mining Exploratory Mission Begins Today. Available online: https:/ / demegsr.com/news/news-deep-seabed-mining-exploratory-mission-begins-today/ (accessed on 7 December 2021).

83. SMD. Deepwater Nodule Collector. Available online: https://www.smd.co.uk/deep-water-nodule-collector-revealed/ (accessed on 9 November 2021).

84. GEOMAR. Environmental Impacts and Risks of Deep-Sea Mining. Available online: https://miningimpact.geomar.de/ (accessed on 24 November 2021).

85. Volkmann, S.E.; Kuhn, T.; Lehnen, F. A comprehensive approach for a techno-economic assessment of nodule mining in the deep sea. Miner. Econ. 2018, 31, 319-336. [CrossRef]

86. Purkiani, K.; Paul, A.; Vink, A.; Walter, M.; Schulz, M.; Haeckel, M. Evidence of eddy-related deep ocean current variability in the North-East Tropical Pacific Ocean induced by remote gap winds. Biogeosciences 2020, 17, 6527-6544. [CrossRef]

87. Gillard, B.; Purkiani, K.; Chatzievangelou, D.; Vink, A.; Iversen, M.H.; Thomsen, L. Physical and hydrodynamic properties of deep sea mining-generated, abyssal sediment plumes in the Clarion Clipperton Fracture Zone (eastern-central Pacific). Elementa 2019, 7, 5. [CrossRef]

88. Purkiani, K.; Gillard, B.; Paul, A.; Haeckel, M.; Haalboom, S.; Greinert, J.; de Stigter, H.; Hollstein, M.; Baeye, M.; Vink, A.; et al. Numerical Simulation of Deep-Sea Sediment Transport Induced by a Dredge Experiment in the Northeastern Pacific Ocean. Front. Mar. Sci. 2021, 1175. [CrossRef]

89. Global Sea Mineral Resources (GSR). Deep-Seabed Mining Robot Patania II Successfully Reconnected. Available online: https:/ / deme-gsr.com/news / deep-seabed-mining-robot-patania-ii-successfully-reconnected-mission-continues/ (accessed on 9 November 2021).

90. Spearman, J.; Taylor, J.; Crossouard, N.; Cooper, A.; Turnbull, M.; Manning, A.; Lee, M.; Murton, B. Measurement and modeling of deep sea sediment plumes and implications for deep sea mining. Sci. Rep. 2020, 10, 5075. [CrossRef]

91. Elerian, M.; Alhaddad, S.; Helmons, R.; van Rhee, C. Near-Field Analysis of Turbidity Flows Generated by Polymetallic Nodule Mining Tools. Mining 2021, 1, 251-278. [CrossRef]

92. Flipse, J.E. An engineering approach to ocean mining. In Proceedings of the Offshore Technology Conference, Houston, TX, USA, 18-21 May 1969.

93. Ito, M. Trend of offshore oil exploration and production. In Proceedings of the Annual Research Report Meeting of JAMSTEC in 2006, Tokyo, Japan, 2 February 2006; pp. 10-13. (In Japanese)

94. US Energy Information Administration. Oil and Petroleum Products Explained. Available online: https://www.eia.gov/ energyexplained/oil-and-petroleum-products / offshore-oil-and-gas-in-depth.php (accessed on 17 November 2021). 